\title{
Psychological Stress Increases Hippocampal Mineralocorticoid Receptor Levels: Involvement of Corticotropin-Releasing Hormone
}

\author{
Angela Gesing, Alicia Bilang-Bleuel, Susanne K. Droste, Astrid C. E. Linthorst, Florian Holsboer, and \\ Johannes M. H. M. Reul
}

Max Planck Institute of Psychiatry, Section of Neuropsychopharmacology, 80804 Munich, Germany

We investigated whether acute stressors regulate functional properties of the hippocampal mineralocorticoid receptor (MR), which acts inhibitory on hypothalamic-pituitary-adrenocortical activity. Exposure of rats to forced swimming or novelty evoked a significant rise in density of MR immunoreactivity in all hippocampal subfields after $24 \mathrm{hr}$, whereas exposure to a cold environment was ineffective. Time course analysis revealed that the effect of forced swimming on MR peaked at $24 \mathrm{hr}$ and returned to control levels between 24 and $48 \mathrm{hr}$. In pyramidal neurons of CA2 and CA3, marked rises were already observed after $8 \mathrm{hr}$. Radioligand binding assays showed that corticotropin-releasing hormone $(\mathrm{CRH})$ injected intracerebroventricularly into adrenalectomized rats also produced a rise in hippocampal MR levels; an effect for which the presence of corticosterone, but not dexamethasone, at the time of injection was a prerequisite. Moreover, pretreatment with the $\mathrm{CRH}$ re-

Glucocorticoid hormones represent the endproduct of the hypothalamic-pituitary-adrenocortical (HPA) axis. They play a principal role in energy metabolism, growth processes, immune function, neuroendocrine control, and brain function, including learning and memory processes underlying behavioral adaptation. Their regulation of the HPA axis has been classified as a negative feedback action and as a tonic inhibitory influence (De Kloet and Reul, 1987; De Kloet et al., 1998). Basically, these two modes of glucocorticoid action are mediated by a dual glucocorticoid-binding receptor system, i.e., the glucocorticoid receptor (GR) and mineralocorticoid receptor (MR) (De Kloet and Reul, 1987; De Kloet et al., 1998), which act as liganddependent transcription factors (Evans and Arriza, 1989). The negative feedback is mediated by GRs at the hypothalamic and pituitary level of the HPA axis (Antoni, 1986; De Kloet and Reul, 1987; Dallman et al., 1987; De Kloet et al., 1998) and in suprahypothalamic structures (Meaney et al., 1996) to restrain circadian-driven and stress-induced elevations in HPA activity. The tonic inhibitory influence of these steroid hormones on HPA activity is exerted via MRs, which are mainly localized in pyramidal $\left(\mathrm{CA}_{1-4}\right)$ and granular (dentate gyrus) neurons of the hippocampus (Gerlach and McEwen, 1972; Herman et al., 1989). This limbic structure restrains HPA activity indirectly via stimulation of inhibitory GABAergic neurons located in the ventrolateral septal region and the bed nucleus of the stria terminalis

\footnotetext{
Received Feb. 6, 2001; revised March 29, 2001; accepted April 5, 2001.

Correspondence should be addressed to Dr. J. M. H. M. Reul, Max Planck Institute of Psychiatry, Section of Neuropsychopharmacology, Kraepelinstrasse 2, D-80804 Munich, Germany. E-mail: reul@mpipsykl.mpg.de.

Copyright (C) 2001 Society for Neuroscience 0270-6474/01/214822-08\$15.00/0
}

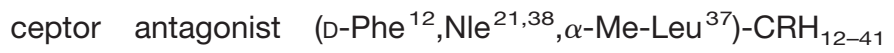
blocked the effect of forced swimming on hippocampal MR levels. To investigate whether the rise in MR levels had any functional consequences for HPA regulation, $24 \mathrm{hr}$ after forced swimming, a challenge test with the MR antagonist RU 28318 was conducted. The forced swimming exposed rats showed an enhanced MR-mediated inhibition of HPA activity.

This study identifies $\mathrm{CRH}$ as an important regulator of $\mathrm{MR}$, a pathway with marked consequence for HPA axis regulation. We conclude that the interaction between $\mathrm{CRH}$ and $\mathrm{MR}$ presents a novel mechanism involved in the adaptation of the brain to psychologically stressful events.

Key words: mineralocorticoid receptor; HPA axis; corticotropinreleasing hormone; ACTH; glucocorticoid hormone; hippocampus; stress

(BNST), which project to corticotropin-releasing hormone $(\mathrm{CRH})$-containing parvocellular neurons of the hypothalamic paraventricular nucleus (Herman and Cullinan, 1997). Beside HPA regulation, MRs affect serotonergic neurotransmission (Joëls et al., 1991; De Kloet et al., 1998), electrophysiological events such as neuronal excitability (Joëls and De Kloet, 1990) and long-term potentiation (Pavlides et al., 1994), and behavioral responses (Oitzl et al., 1994; Smythe et al., 1997; Bitran et al., 1998).

The concept on the tonic inhibitory function of hippocampal MR on the activity of the HPA axis stems primarily from receptor occupancy studies. These studies showed that, because of the high affinity for endogenous glucocorticoids $\left(K_{\mathrm{d}} \cong 0.1-0.5 \mathrm{nM}\right)$, MRs are $>80 \%$ occupied already at the trough of the diurnal HPA cycle (Reul and De Kloet, 1985; Reul et al., 1987a, 1990; Spencer et al., 1990). This concept was further substantiated by the observation that intracerebroventricular and intrahippocampal injection of the synthetic MR antagonist RU 28318 resulted in an elevation of baseline corticosterone levels (Ratka et al., 1989; Oitzl et al., 1995; Van Haarst et al., 1997). However, the situation of a receptor (i.e., MR), which is always to a large extent occupied by hormone, prompts the question whether we are dealing with a static or a dynamic receptor system. A static system would be merely playing a cofactor function, whereas, in contrast, a dynamic receptor system would be responding, in terms of its capacity and function, rapidly to changing requirements. For GR this is much less relevant because this receptor becomes occupied in a graded manner by glucocorticoids during different physiological conditions (cf. circadian trough and peak, stress) (Reul and De Kloet, 1985; Reul et al., 1987a, 1990). Therefore, with regard 
to MR, we contemplated that, if the function of MR were to respond adequately to changing physiological conditions and needs, then an appropriate means would be to dynamically change its receptor capacity. Here, we show that an acute psychologically stressful experience raises hippocampal MR density, an event that is associated with an increased MR-mediated inhibition of HPA activity.

\section{MATERIALS AND METHODS}

\section{Animals and surgery}

Male Wistar rats (weight at time of experiment 220-240 gm) were group-housed six per cage with ad libitum access to food and water in a light (lights on from 6.00 A.M. until 20.00 P.M.)-, temperature (22 \pm $\left.1{ }^{\circ} \mathrm{C}\right)$-, and humidity $(55 \pm 5 \%)$-controlled animal room. Animals with intracerebroventricular cannulas were housed singly. All rats were handled at least $7 \mathrm{~d}(\sim 3 \mathrm{~min} /$ rat per day) before the day of the experiment. All experimental protocols were approved by the Ethical Committee on Animal Care and Use of the Government of Bavaria, Germany.

In some experiments, bilaterally adrenalectomized rats were used. Adrenalectomy (ADX) was performed aseptically under halothane anesthesia $1 \mathrm{~d}$ before application of stress or intracerebroventricular injection. After adrenalectomy, rats were given $0.9 \%$ saline in their drinking water and, in some experimental groups, corticosterone $(15 \mu \mathrm{g} / \mathrm{ml})$ or dexamethasone $(5 \mu \mathrm{g} / \mathrm{ml})$ was added as well. Steroids were first dissolved in ethanol before being added to the drinking solution (final concentration $0.5 \%$ ethanol). In some experiments, rats were equipped with an intracerebroventricular cannula. This operation was conducted 1 week before the experiment under halothane anesthesia using a stereotactic instrument (coordinates: lateral, $-1.2 \mathrm{~mm}$; anteroposterior, $+0.5 \mathrm{~mm}$ ).

\section{Experimental procedures}

Effect of forced swimming, cold exposure, and novelty on hippocampal MR immunoreactivity. All experiments were started between 7:00 and 9:00 A.M. To determine the effect of forced swimming on MR immunoreactivity, rats were placed in a glass beaker containing water (height, $20 \mathrm{~cm}$ ) at $25^{\circ} \mathrm{C}$ for $15 \mathrm{~min}$. Thereafter, they were dried and returned to their home cage. To induce novelty stress, rats were placed singly in a new cage for $30 \mathrm{~min}$. Cold exposure consisted of placing the animals singly in a cage at $4^{\circ} \mathrm{C}$ for $4 \mathrm{hr}$ without access to food and water. Thereafter rats were returned to their home cages. Control animals were kept undisturbed in their home cages. Twenty-four hours later rats were killed by decapitation under quiet conditions. Whole brains to be used for MR immunohistochemistry (see below) were snap-frozen in isopentane at $-40^{\circ} \mathrm{C}$ and deep-frozen in dry-ice.

In a separate experiment, a time course was determined for the effect of forced swimming on MR immunoreactivity in the hippocampus. Therefore, rats were killed at 8,24 , or $48 \mathrm{hr}$, or at $7 \mathrm{~d}$ after forced swimming.

Effect of CRH on hippocampal MR and GR binding: involvement of glucocorticoids. To assess whether CRH could mimic the effects of stress on MR, $1 \mathrm{~d} \mathrm{ADX}$ rats were injected intracerebroventricularly with $\mathrm{CRH}$ ( $3 \mu \mathrm{g}$ in $10 \mu \mathrm{l}$ saline) or saline only. To test for glucocorticoid involvement, separate groups of ADX rats were supplemented with corticosterone, dexamethasone, or no-steroid via the drinking solution from the time of surgery until the time of injection. Immediately after the intracerebroventricular injection, glucocorticoids were withdrawn from the animals' drinking solution because they would hamper the receptor binding assay (see below). Twenty-four hours after injection, rats were killed under quiet conditions to prevent acute unspecific stress. Next, various regions (to be used in the in vitro MR and GR binding assay) were dissected from the brain and frozen in liquid nitrogen. Plasma was prepared from trunk blood to check for the completeness of adrenalectomy.

Effect of forced swimming on MR: intermediary role of $C R H$. Corticosterone-substituted $1 \mathrm{~d}$ ADX rats were subjected to forced swimming $\left(15 \mathrm{~min}\right.$ at $\left.25^{\circ} \mathrm{C}\right)$ or left untouched in their home cages (i.e., control). Ten minutes before the forced swimming procedure, rats received an intracerebroventricular injection with either CRH receptor antagonist (D-Phe ${ }^{12}, \mathrm{Nle}^{21,38}, \alpha-\mathrm{Me}-\mathrm{Leu}^{37}$ )- $\mathrm{CRH}_{12-41}$ (D-Phe-CRH ${ }_{12-41}$; $5 \mu \mathrm{g}$ in $10 \mu \mathrm{l}$ saline) or vehicle. Directly after forced swimming, the corticosterone-containing drinking solution was replaced by saline. Rats were killed $24 \mathrm{hr}$ later. The brain was dissected, and various parts (for in vitro MR and GR binding assay) were frozen in liquid nitrogen.
$R U 28318$ challenge test. To determine whether the changes in MR levels in the hippocampus resulted in an altered MR-mediated tonic inhibitory control of the HPA axis, a challenge test with the specific MR antagonist RU 28318 was conducted. Rats were subjected to forced swimming or left undisturbed. Twenty-four hours later, RU 28318 (100 ng in $0.5 \%$ ethanol/saline) or the vehicle was injected intracerebroventricularly, and rats were decapitated 30 min later. After decapitation, blood was collected in ice-chilled EDTA-coated Trasylol-containing tubes, and plasma was prepared to be used for radioimmunoassay for ACTH and corticosterone content (Reul et al., 1993).

\section{Immunohistochemistry}

Twenty micrometer coronal brain cryosections were mounted on polylysine-coated slides and post-fixed for $30 \mathrm{~min}$ in $4 \%$ paraformaldehyde. Subsequent immunohistochemical staining was performed with the avidin-biotin-peroxidase system (Elite ABC goat kit; Vector Laboratories, Burlingame, CA) and diaminobenzidine $/ \mathrm{Ni}^{+}$as substrate according to company instructions. Detection of MR was achieved using a primary polyclonal goat anti-MR antibody (N-17; dilution 1:800; Santa Cruz Biotechnology, Santa Cruz, CA). As negative controls, purified IgGs from normal goat (Santa Cruz) serum were used. Specificity of primary antibodies was checked by both antigen preabsorption and Western analysis (data not shown). The immunohistochemical signal of MR-IR was quantified using a digital video image analyzer (Optimas System, Puchheim, Germany). The staining intensity (i.e., gray values) of nuclei of all neurons of the pyramidal and granular cell layers within an area of $320 \times 410 \mu \mathrm{m}$ (as shown in Fig. 1) was analyzed. From each animal, at least three sections of independent immunohistochemical assays were evaluated. The net immunohistochemical staining was determined by subtraction of the background signal from the nuclear staining signal. Data are presented as mean gray values \pm SEM of six rats per group, except for the cold stress experiment $(n=4-5)$.

\section{Receptor binding assay}

The MR and GR binding assay was conducted as described (Reul et al., 1993). Briefly, pooled brain tissues were homogenized $(100 \mathrm{mg}$ tissue $/ \mathrm{ml}$; 10 strokes at $900 \mathrm{rpm}$ ) in ice-cold $5 \mathrm{~mm}$ Tris- $\mathrm{HCl}, \mathrm{pH} 7.4$, containing $5 \%$ glycerol, $1 \mathrm{~mm}$ EDTA, $10 \mathrm{~mm}$ sodium molybdate, and $2 \mathrm{~mm}$ $\beta$-mercaptoethanol using a glass homogenizer with a Teflon pestle milled at a clearance of $0.25 \mathrm{~mm}$ on the radius. The homogenate was centrifuged at $100,000 \times g$ for $60 \mathrm{~min}$ at $0-2^{\circ} \mathrm{C}$ to obtain cytosol (i.e., the supernatant fraction). Aliquots of cytosol were incubated for $20 \mathrm{hr}$ at $4^{\circ} \mathrm{C}$ with $\left[{ }^{3} \mathrm{H}\right]$-aldosterone and $\left[{ }^{3} \mathrm{H}\right]$-dexamethasone at a concentration range of $0.05-10 \mathrm{~nm}$ to measure MR and GR, respectively. In [ $\left.{ }^{3} \mathrm{H}\right]$-aldosteronecontaining incubations, a 100-fold excess of the specific GR ligand RU 28362 was included to block binding of $\left[{ }^{3} \mathrm{H}\right]$-aldosterone to GR. The binding of $\left[{ }^{3} \mathrm{H}\right]$-dexamethasone to MR was evaluated by adding a 100 fold excess of RU 28362. Nonspecific binding for MR and GR was determined by inclusion of a 1000 -fold excess of corticosterone and dexamethasone, respectively. Bound and free $\left[{ }^{3} \mathrm{H}\right]$-steroid were separated by gel filtration on Sephadex LH-20 (Pharmacia, Uppsala, Sweden), and bound radioactivity was measured by liquid scintillation counting. Protein content was determined by the method of Lowry using BSA as a standard. The binding data were expressed as femtomoles per milligram of protein, and nonspecific binding was subtracted from total binding to yield specific binding. GR levels were calculated by subtraction of nonspecific binding as well as binding of $\left[{ }^{3} \mathrm{H}\right]$-dexamethasone to MR. Total binding $\left(B_{\max }\right)$ and binding affinity $\left(K_{\mathrm{d}}\right)$ were derived from Scatchard analysis.

\section{Radioimmunoassay}

Blood samples were centrifuged at $4^{\circ} \mathrm{C}$ for $10 \mathrm{~min}$, and plasma aliquots were stored at $-80^{\circ} \mathrm{C}$ for analysis by radioimmunoassay (ICN Biomedicals, Costa Mesa, CA) as described previously (Reul et al., 1993). The interassay and intra-assay coefficients of variance for ACTH were 7 and $5 \%$, respectively, with a detection limit of $2 \mathrm{pg} / \mathrm{ml}$. For corticosterone, the interassay and intra-assay coefficients of variance were 7 and $4 \%$, respectively, with a detection limit of $1.5 \mathrm{ng} / \mathrm{ml}$.

\section{Statistics}

Data were analyzed with Student's $t$ test, one-way ANOVA followed by a Dunnett's $t$ test, or two-way ANOVA followed by a post hoc Duncan multiple range test. The experimental data were considered to be statistically different from control data when $p<0.05$. 

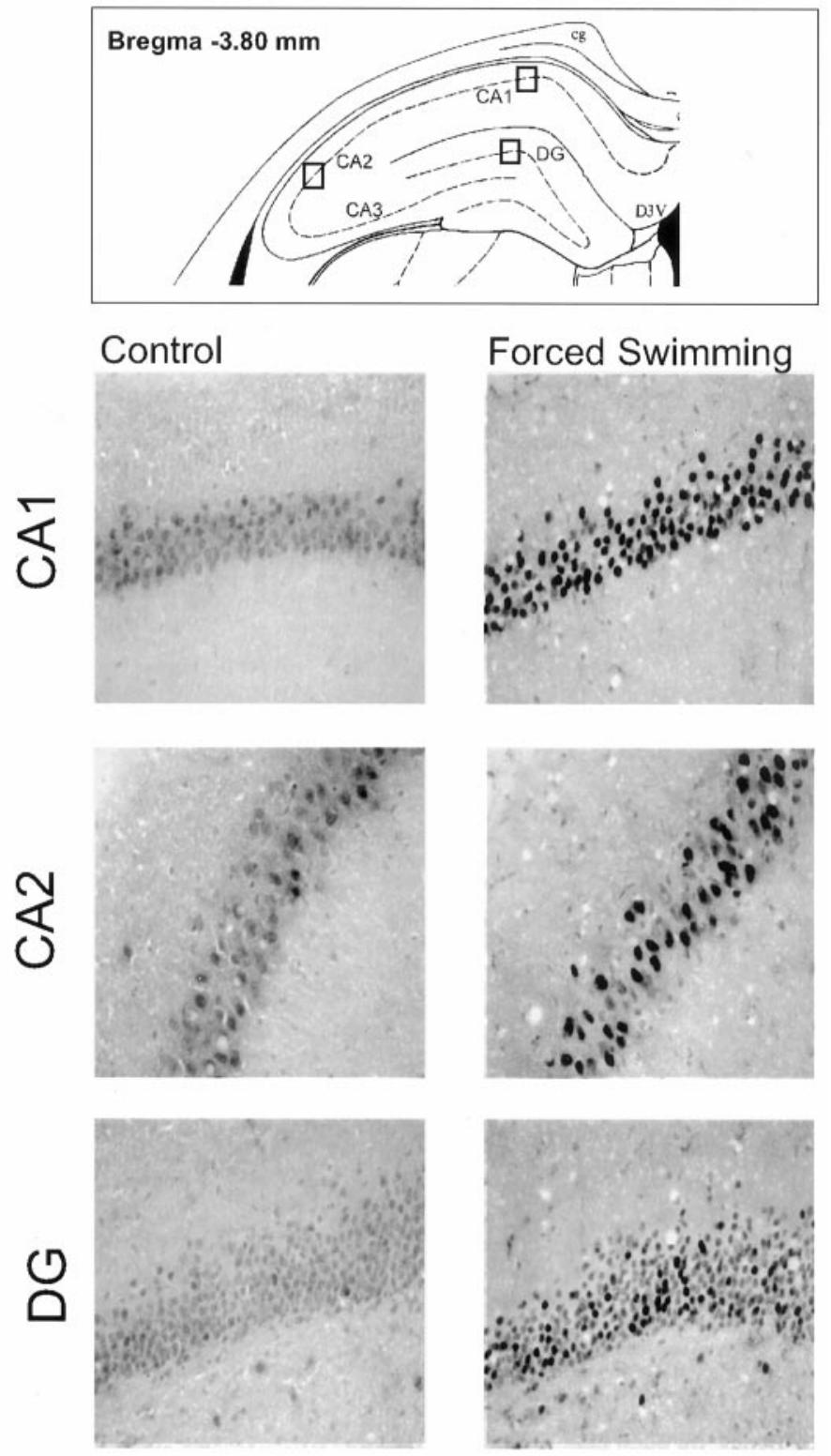

Figure 1. Increase in MR-IR in neuronal nuclei of CA1, CA2, and dentate gyrus (DG) $24 \mathrm{hr}$ after a 15 min session of forced swimming (water temperature, $25^{\circ} \mathrm{C}$ ). Representative immunohistochemical pictures are shown together with their localization in the hippocampus at level $-3.8 \mathrm{~mm}$ of bregma. All images are equally magnified $(200 \times)$. Please note the nuclear localization of MR in the pyramidal and granular layers. $c g$, Cingulum bundle; $D 3 V$, dorsal part of third ventricle. For quantitative analyses, see Figure 2.

\section{RESULTS}

\section{Effect of forced swimming, cold exposure, and novelty} on hippocampal MR immunoreactivity

Rats were subjected to a single forced swim session, and $24 \mathrm{hr}$ later MR density in hippocampus was determined by semiquantitative immunohistochemistry. Analysis of MR immunoreactivity (MR-IR) in rat brain sections revealed a similar distribution, as previously reported using in vitro autoradiography and in situ hybridization (Reul and De Kloet, 1986; Herman et al., 1989). The hippocampus proved to be the richest source of MR-IR with highest levels in the pyramidal neurons. Within the different regions, a heterogeneous intensity of (nuclear) staining among neurons was observed (Fig. 1). Twenty-four hours after forced swimming, a rise in the average staining intensity of MR-IR was found in all cell layers of the hippocampus (Fig. 1), which was confirmed by semiquantitative image analysis (Fig. $2 A$ ). It was, however, evident that also after stress a marked heterogeneity in signal intensity among neurons was maintained. Beside forced swimming, we also found novelty stress, a mild psychological stressor (Fig. 2B), but not cold exposure (Fig. 2C), to increase hippocampal MR expression.

Time course analysis of the effect of forced swimming on MR levels in the cellular subfields of the hippocampus revealed significant rises at $24 \mathrm{hr}$, whereas in CA2 and CA3 also at $8 \mathrm{hr}$ significant elevations could be observed (Fig. 3). At $48 \mathrm{hr}$, in all subfields MR levels had returned to baseline values.

\section{Effect of CRH on hippocampal MR and GR binding: involvement of glucocorticoid hormones}

Using a radioligand binding method, we investigated whether CRH would mimic the effects of forced swimming and novelty on hippocampal MR levels. With this method, we could also determine GR levels. Because corticosteroid receptor binding characteristics (i.e., $B_{\max }, K_{\mathrm{d}}$ ) can only be reliably determined in corticosteroid-free tissue, initial experiments were conducted in adrenalectomized rats. This approach also allowed us to control for CRH-induced (and stress-induced, see below) endogenous secretion of glucocorticoids, which are known to regulate brain MR and GR levels (Reul et al., 1987b; Spencer et al., 1991).

Intracerebroventricular injection of $\mathrm{CRH}$ produced no significant effect on hippocampal MR levels (Fig. 4A). We contemplated that endogenous corticosterone might be required to permit a CRH-evoked rise in receptor levels. Therefore, we supplemented the drinking solution of the ADX rats with a physiological dose of corticosterone (i.e., $15 \mu \mathrm{g} / \mathrm{ml}$ ) until we gave the CRH-vehicle injection, after which a normal, steroid-free solution was given. Indeed, in corticosterone-substituted animals, CRH evoked a marked rise in hippocampal MR levels (Fig. 4A). In contrast, if rats were substituted with the selective GR agonist dexamethasone, $\mathrm{CRH}$ produced a profound decrease in MR levels (Fig. 4A). However, hippocampal tissue of dexamethasonesubstituted control rats showed higher levels of MR than nosteroid and corticosterone-substituted animals; a well known, but still unclarified phenomenon (Reul et al., 1987b, 1989). At any rate, dexamethasone application obviously did not allow a CRHinduced rise of MR, suggesting that the effect of CRH on this receptor type involved a permissive glucocorticoid effect via MR and not GR. CRH application did not affect GR levels (Fig. 4B). In none of the experiments the ligand binding affinity of either MR or GR was affected (data not shown).

\section{Effect of forced swimming on MR: intermediary role of $\mathrm{CRH}$}

We next investigated whether the effect of forced swimming would be evoked by a CRH receptor-mediated action. Given the necessity of the presence of corticosterone in the previous experiment, ADX rats were substituted with corticosterone until the forced swim session. Forced swimming evoked a marked rise in MR levels (Fig. 5), confirming the data obtained with immunohistochemistry (Figs. 1, 2). No effects were apparent on GR (data not shown). The same results were found using in vitro autoradiography of MR binding in brain sections (data not shown). Pretreatment of rats intracerebroventricularly with D-Phe$\mathrm{CRH}_{12-41} 10 \mathrm{~min}$ before forced swimming blocked the effect of 


\section{A}
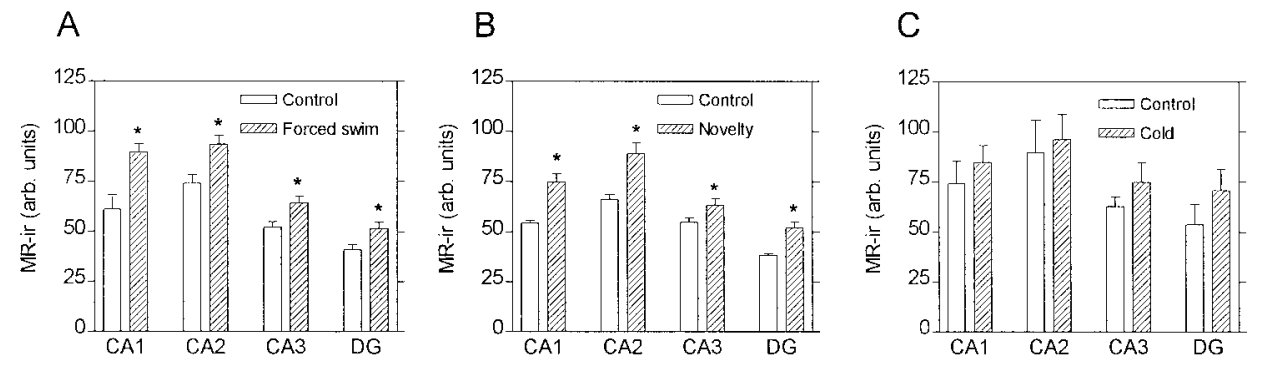

Figure 2. Effect of forced swimming (15 min at $\left.25^{\circ} \mathrm{C} ; A\right)$, novelty (30 min in new cage; $B$ ), and cold exposure $\left(4 \mathrm{hr}\right.$ at $\left.4^{\circ} \mathrm{C} ; C\right)$ on MR-IR in neuronal nuclei of CA1, CA2, CA3, and DG after $24 \mathrm{hr}$. Optical densities of neuronal nuclei were determined by an image analysis program. MR-IR data are expressed as arbitrary units (net gray level). Data in $A(n=6$ rats), $B(n=6)$, and $C(n=4-5)$ are presented as mean \pm SEM. $* p<0.05$, if compared with respective control (Student's $t$ test).
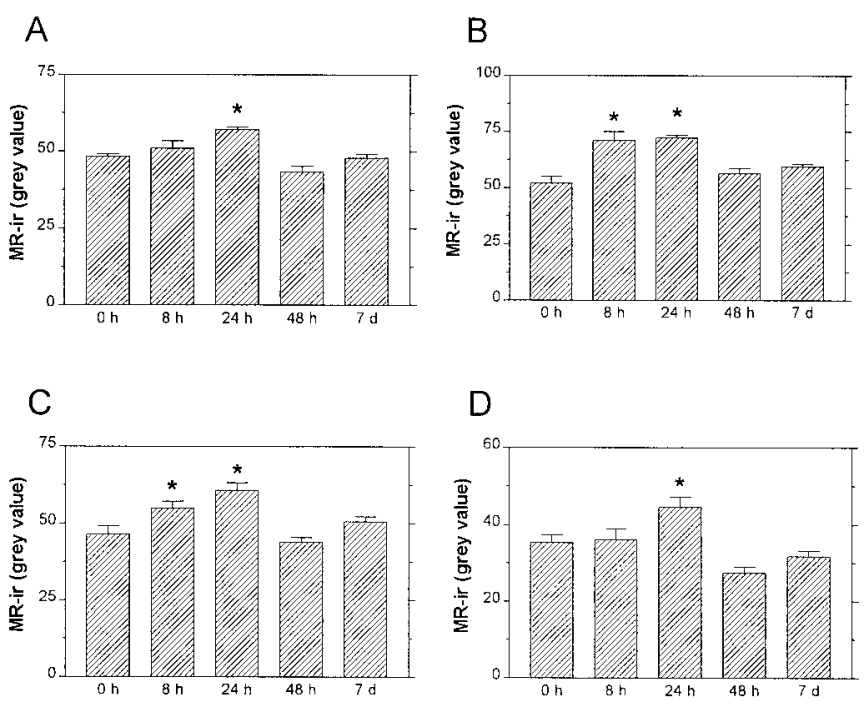

Figure 3. Time course analysis of the effect of forced swimming on MR-IR in neuronal nuclei of CA1 $(A), \mathrm{CA} 2(B), \mathrm{CA} 3(C)$, and DG $(D)$. Rats ( $n=6$ per group) were killed under early morning baseline conditions $(0 \mathrm{~h})$ or $8 \mathrm{hr}, 24 \mathrm{hr}, 48 \mathrm{hr}$, or $7 \mathrm{~d}$ after a single forced swimming session $\left(15 \mathrm{~min}\right.$ at $\left.25^{\circ} \mathrm{C}\right) .{ }^{*} p<0.05$ if compared with $0 \mathrm{hr}$ controls, post hoc Dunnett's test.

\section{A}

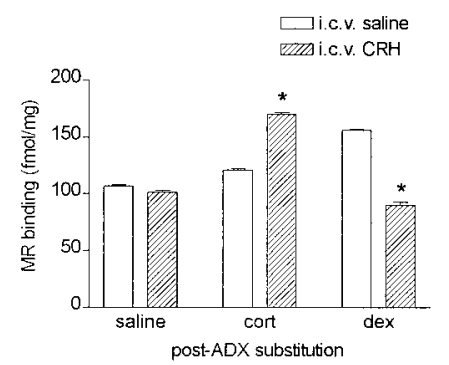

B

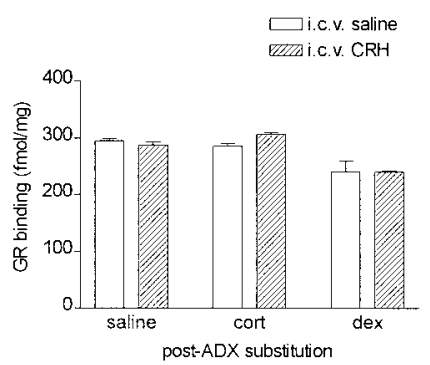

Figure 4. Effect of intracerebroventricular injection of saline or $3 \mu \mathrm{g}$ of $\mathrm{CRH}$ on $\mathrm{MR}(A)$ and GR $(B)$ binding in hippocampus of corticosterone, dexamethasone, and nonsubstituted ADX rats. After the CRH injection procedure, rats received no-steroid-containing $0.9 \% \mathrm{NaCl}$ in tap water to drink. All animals were killed $24 \mathrm{hr}$ later, and hippocampal MR and GR binding was determined by a radioligand binding assay (see Materials and Methods). Data (femtomoles per milligram of protein) are expressed as mean \pm SEM of five independent experiments. ${ }^{*} p<0.05$, if compared with the respective intracerebroventricular saline group (post hoc Duncan multiple range test).

the stressor on MR levels (Fig. 5), strongly suggesting an important intermediary role of $\mathrm{CRH}$ receptors. In addition to hippocampus, forced swimming evoked increases in MR concentrations in neocortex, frontal cortex, and amygdala (but not

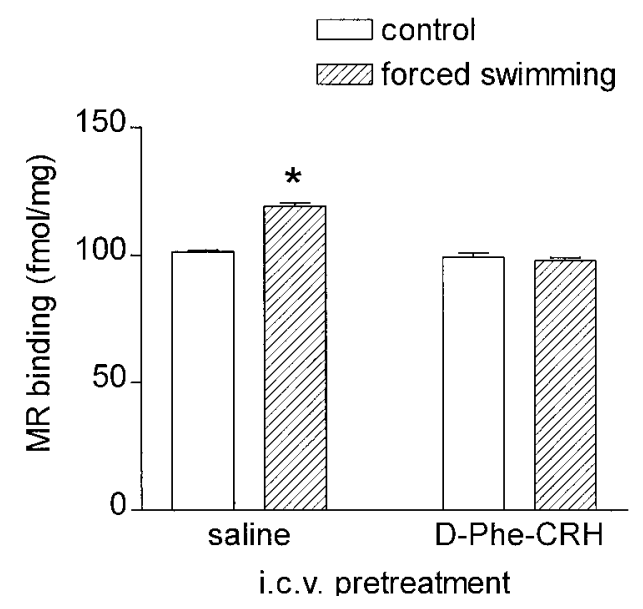

Figure 5. Effect of forced swimming on hippocampal MR is mediated by the $\mathrm{CRH}$ receptor. Ten minutes before a 15 min forced swimming session (water temperature $25^{\circ} \mathrm{C}$ ), corticosterone-substituted $\mathrm{ADX}$ rats were intracerebroventricularly injected with $5 \mu \mathrm{g}$ of D-Phe-CRH $\mathrm{CR}_{12-41}$ or vehicle. After the forced swimming procedure, rats received no-steroidcontaining $0.9 \% \mathrm{NaCl}$ in tap water to drink. All animals were killed $24 \mathrm{hr}$ later, and MR binding was determined by a radioligand binding assay. Data (femtomoles per milligram of protein) are expressed as mean \pm SEM of five independent experiments. ${ }^{*} p<0.05$, if compared with the respective intracerebroventricular saline group (post hoc Duncan multiple range test).

hypothalamus) that were completely abolished by D-Phe$\mathrm{CRH}_{12-41}$ (Table 1). Thus, the effect of forced swim stress on MR levels is confined to extrahypothalamic limbic and neocortical brain regions and is mediated by an action via $\mathrm{CRH}$ receptors within the brain.

\section{Forced swimming-induced rise in hippocampal MR levels: implications for HPA axis activity}

The hippocampal MR mediates a tonic inhibitory influence of low levels of corticosterone on the HPA axis, as was shown in neuroendocrine challenge tests in rats and humans using MR antagonists such as RU 28318 and spironolactone (Ratka et al., 1989; Deuschle et al., 1998). Pharmacologically, the action of the antagonists is based on the high occupancy of MRs by endogenous glucocorticoids already at the trough of HPA activity (Reul and De Kloet, 1985; De Kloet and Reul, 1987; Reul et al., 1987a, 2000; Spencer et al., 1990). Hence, application of MR antagonists evolves in transient rises in plasma ACTH and glucocorticoid hormone levels (Ratka et al., 1989). We applied an RU 28318 challenge to explore the functional significance of stress-induced elevations in hippocampal MR. In control rats, RU 28318 injection led to increases in plasma ACTH and corticosterone, but they did not reach statistical significance (Fig. 6). However, in rats stressed by forced swimming $24 \mathrm{hr}$ before, the MR antagonist produced marked rises in plasma corticosterone $(p<0.05)$ and 
Table 1. Blockade of forced swimming-induced rise in MR levels by D-Phe-CRH ${ }_{12-41}$

\begin{tabular}{|c|c|c|c|c|}
\hline & $\begin{array}{l}\text { Saline/control } \\
\text { (i.c.v.) }\end{array}$ & $\begin{array}{l}\text { Saline/stress } \\
\text { (i.c.v.) }\end{array}$ & $\begin{array}{l}\text { D-Phe-CRH }{ }_{12-41} / \text { control } \\
\text { (i.c.v.) }\end{array}$ & $\begin{array}{l}\text { D-Phe-CRH }{ }_{12-41} / \text { stress } \\
\text { (i.c.v.) }\end{array}$ \\
\hline Hippocampus & $101.3 \pm 0.6$ & $119.1 \pm 1.2^{*}$ & $99.2 \pm 1.6$ & $97.8 \pm 1.2$ \\
\hline Neocortex & $21.3 \pm 1.6$ & $26.9 \pm 0.3^{*}$ & $21.8 \pm 0.7$ & $21.8 \pm 0.2$ \\
\hline Amygdala & $27.8 \pm 0.7$ & $33.1 \pm 0.4^{*}$ & $29.2 \pm 1.4$ & $31.0 \pm 0.9$ \\
\hline Frontal cortex & $14.7 \pm 0.4$ & $23.8 \pm 0.3^{*}$ & $14.7 \pm 0.2$ & $15.7 \pm 1.3$ \\
\hline Hypothalamus & $16.8 \pm 0.7$ & $16.2 \pm 0.3$ & $14.2 \pm 0.2$ & $14.7 \pm 0.5$ \\
\hline
\end{tabular}

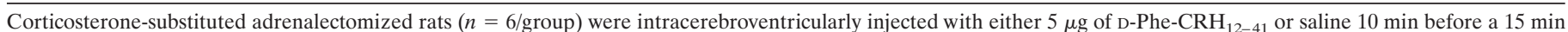

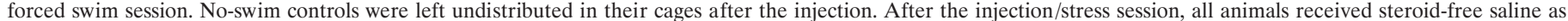

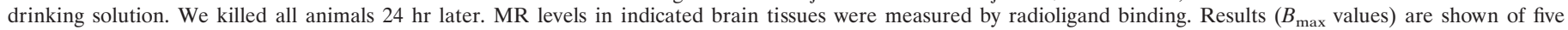

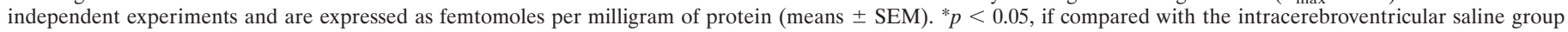
(post hoc Duncan multiple range test).

A

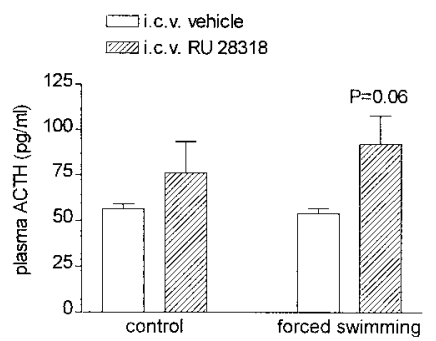

B

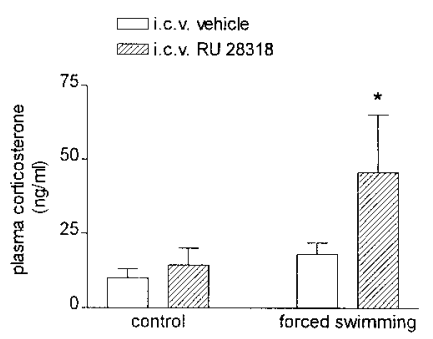

Figure 6. Increased MR-mediated HPA axis inhibition $24 \mathrm{hr}$ after forced swimming. Twenty-four hours after a $15 \mathrm{~min}$ forced swim period, rats were intracerebroventricularly injected with the MR antagonist RU 28318 (100 ng in $10 \mu \mathrm{l}$ of $0.5 \%$ ethanol/saline) or vehicle. Animals were decapitated $30 \mathrm{~min}$ later, and trunk blood was collected. Data $(n=5-7)$ on ACTH (in picograms per milliliter) $(A)$ and corticosterone (in nanograms per milliliter) $(B)$ plasma concentrations are presented as mean \pm SEM. ${ }^{*} p<0.05$, if compared with respective intracerebroventricular vehicle (post hoc Duncan multiple range test).

ACTH $(p=0.06)$ (Fig. 6). Thus, stress-induced rises in MR density are associated with profoundly higher hormonal responses to an MR antagonist challenge. This observation indicates that within $24 \mathrm{hr}$ after a stressful experience an enhancement occurs in the MR-mediated tonic inhibitory control of the HPA axis.

\section{DISCUSSION}

Here, we showed that psychologically stressful events such as novelty and forced swimming induced a rise in hippocampal MR levels that was associated with changes in the regulatory control of the HPA axis. Elevations in MR density were evident in nuclei of pyramidal and granular neurons in all hippocampal subfields. The stress-induced rises were transient and peaked at $24 \mathrm{hr}$, whereas in CA2 and CA3, significant elevations were already seen at $8 \mathrm{hr}$. Notably, CRH mediated the effect of forced swim stress on MR for which the presence of corticosterone was a prerequisite. In addition to the hippocampus, forced swimming-induced, $\mathrm{CRH}$ receptor-mediated rises in MR were observed in the amygdala and neocortical regions, including the frontal cortex. The effects were specific with regard to MR, because no effects on GR levels were found. The rise in MR was associated with an increased, MR-mediated tonic inhibition of HPA activity. Thus, the capacity and function of MR is under a dynamic control participating in HPA and, most likely, other changes in the brain after a stressful challenge.

Apart from neuroanatomical specificity, the response in MR was stressor-specific. Forced swimming and novelty stress evoked an increase in MR density, whereas cold exposure was ineffective.
This stressor specificity may reflect the involvement of limbic and neocortical forebrain structures required for appropriate interpretation of the situation, which is in line with the concept on the differential circuitry involved in the processing in the brain of psychological (cf. novel environment, forced swimming) versus physical (cf. cold exposure) stress (Herman and Cullinan, 1997). This notion is underlined by the observation that stress-evoked rises were only observed in extrahypothalamic limbic and neocortical brain regions. Previously, restraint stress was shown to reduce MR heteronuclear RNA, but not MR mRNA, in DG and CA1 within 1-2 hr (Herman and Watson, 1995). Our preliminary data show that forced swimming did not affect MR mRNA levels in the rat hippocampus (data not shown). In tree shrews subjected to chronic psychosocial stress, within the hippocampus elevations as well as reductions in MR mRNA levels were observed (Meyer et al., 2000). In conjunction with our data, this suggests that psychological stress differentially affects MR gene transcription and translation.

We found that CRH plays an important role in the effect of forced swimming on the density of MR in the hippocampus and other extrahypothalamic parts of the brain. $\mathrm{CRH}$ might have evoked this effect on MR directly or indirectly. A direct action of $\mathrm{CRH}$ may have evolved via $\mathrm{CRH}$ receptors that are known to be present in the hippocampus, neocortex, and amygdala (Chalmers et al., 1995). Indirectly, CRH activates several neurotransmitter systems, including the serotonergic (Linthorst et al., 1999) and noradrenergic systems (Curtis et al., 1997), which exert positive effects on corticosteroid receptor expression (Mitchell et al., 1990; Seckl et al., 1990; Maccari et al., 1992; Vedder et al., 1993). Our study identifies CRH as an important regulator of MR expression in certain brain areas. Conceptually, this interaction presents a novel element in the function of $\mathrm{CRH}$ in the stress response. Until now, CRH is regarded as the key mediator of neuroendocrine, autonomic, and behavioral responses to stress (Owens and Nemeroff, 1991; Holsboer, 1999). Evidently, by its effects on MR expression, $\mathrm{CRH}$ with regard to its time point acts beyond the acute phase of the stress response and participates in the regulation of a primary control instrument of the HPA axis, i.e., MR. This interaction adds a new component to the regulation of the HPA axis: the notion that a proactively acting HPA neuropeptide (i.e., CRH) strengthens an HPA axis controlling instrument (i.e., MR). In addition to HPA regulation, MR regulates autonomic output and stress-related behavioral performance (Korte et al., 1993; Oitzl et al., 1994). On the cellular level, hippocampal MR reduces serotonergic signal transduction (Joëls et al., 1991; Meijer and De Kloet, 1998), potentiates electrical activity of pyramidal neurons (Joëls and De Kloet, 1990), extends long-term potentia- 
tion (Pavlides et al., 1994), and has anti-apoptotic properties in the dentate gyrus (Sloviter et al., 1989; Hassan et al., 1997). This underlines that the effect of $\mathrm{CRH}$ on MR function comprises a general organizational change in the stress response, possibly as part of adaptive processes. Also urocortin could play a role in this mechanism because this $\mathrm{CRH}$-like neuropeptide binds with high affinity to both CRH-R1 and CRH-R2 (Vaughan et al., 1995). Therefore, future investigations should reveal whether $\mathrm{CRH}$ or urocortin is recruited by the effect of psychological challenges on MR and whether this evolves via CRH-R1 or CRH-R2.

The presence of corticosterone was a prerequisite for the effects of CRH on MR, because no effects were seen in nonsubstituted ADX rats. High glucocorticoid levels are known to affect corticosteroid receptor expression (Reul et al., 1987b, 1989; De Kloet et al., 1998) and, therefore, the use of ADX rats and steroid substitution allowed to control for indirect effects of stress and $\mathrm{CRH}$ on MR via elevations in corticosterone because of HPA axis activation. The plasma levels of corticosterone in ADX rats attained after substitution of this steroid were in the same range as found during the early morning hours in intact rats, i.e., $<10$ $\mathrm{ng} / \mathrm{ml}$. Thus, these low levels of corticosterone sufficed to allow $\mathrm{CRH}$-induced upregulation of MR levels. However, substitution of ADX rats with dexamethasone was ineffective in allowing MR upregulation. In contrast, as shown before (Reul et al., 1987b, 1989, 2000), dexamethasone treatment itself induced an upregulation of MR, the mechanism of which is still unknown. Under these conditions, CRH injection caused a reduction in MR levels. Presently, the interaction between dexamethasone and CRH is unclear, but it is clearly distinct from the stimulatory effects of stress and $\mathrm{CRH}$ on MR in corticosterone-substituted and intact animals. Nevertheless, given the differential in vivo receptor binding profile of dexamethasone (GR) versus low corticosterone (MR), it appears that MR occupancy by corticosterone is required for the stimulatory effects of $\mathrm{CRH}$ on MR levels.

The RU 28318 challenge test showed that the forced swimming-evoked increase of hippocampal MR levels was accompanied by an enhanced MR-mediated inhibitory tonus on the activity of the HPA axis. This observation underscores that the changes in MR density are of physiological significance. However, in view of the increased MR-mediated inhibition of HPA activity $24 \mathrm{hr}$ after forced swimming or novelty stress, reduced ACTH and corticosterone plasma were to be expected, but did not occur (data not shown). This observation points to the involvement of compensatory mechanisms aimed to balance the enhanced tonic inhibition and, thus, to maintain "normal" baseline HPA output. Such mechanisms might act at different levels of the HPA axis: intrahypothalamic circuits modulating the corticotrophic secretory system, corticotrophic sensitivity in the anterior pituitary, and adrenal mechanisms. Alternatively, afferent pathways within the CNS might convey stimulatory influences to the HPA axis (Whitnall, 1993), such as those originating in the central nucleus of the amygdala and the thalamic paraventricular nucleus (Bhatnagar and Dallman, 1998). Thus, an overall adjustment in the afferent control of the HPA axis occurs after emotional and psychological stress.

The newly acquired insight into the interaction between $\mathrm{CRH}$ and MR after stressful events is of importance for the elucidation of the pathophysiology of stress-related disorders such as major depression. Depressed patients show elevated cerebrospinal fluid levels of CRH (Nemeroff et al., 1984), increased numbers of CRH and $\mathrm{CRH} /$ vasopressin-expressing neurons in their paraventricular nucleus (PVN) (Raadsheer et al., 1994), and elevated CRH
mRNA levels in this nucleus (Raadsheer et al., 1995). Reduced levels of CRH-binding sites have been measured in brains of suicide victims having suffered from depression (Nemeroff et al., 1988), and also neuroendocrine function tests favor elevated CRH secretion in depressed patients (Holsboer et al., 1984; Gold et al., 1986). Thus, a hyperactivity of $\mathrm{CRH}$ very likely exists in depressed patients, which is at least partly responsible for the elevated HPA activity, the vegetative disturbances, and psychopathology observed in these patients (Holsboer, 2000). The HPA aberrations seen in depression seem to involve disturbed MR function (De Kloet et al., 1998; Lopez et al., 1998; Reul et al., 2000), whereas their role in autonomic and psychological aspects of the disease is still unknown. Successful antidepressant drug treatment, besides amelioration of psychopathology, results in normalization of HPA function (Holsboer and Barden, 1996; De Kloet et al., 1998). Animal studies have revealed that chronic antidepressant treatment primarily raises hippocampal MR density, which is thought to be instrumental in the observed attenuation of parvocellular paraventricular CRH expression and HPA axis activity (Brady et al., 1991; Reul et al., 1993, 1994). Decreased hippocampal MR density and increased CRH expression, often associated with HPA hyperactivity, have also been observed in aging animals and man (Meaney et al., 1988, 1992; Reul et al., 1988; Swaab et al., 1994; Raadsheer et al., 1995). We postulate that hypersecretion of CRH in brain resulting from chronic stress or during aging leads, via desensitization of $\mathrm{CRH}$ receptors and post-receptor systems, to a decline in the CRH-mediated regulation of MR levels resulting in a growing loss of control of the HPA axis and other MR-sensitive systems. Whether it comes in individuals to this aberrant CRH-MR interaction seems to depend on the person's genetic make-up, frequency, and gravity of major life events, age, and early life experiences (Levine, 1967; Meaney et al., 1988, 1989; Sutanto et al., 1996; Vallée et al., 1997; De Kloet et al., 1998; Holsboer, 2000).

\section{REFERENCES}

Antoni FA (1986) Hypothalamic control of adrenocorticotropin secretion: advances since the discovery of 41-residue corticotropin releasing factor. Endocr Rev 7:351-378.

Bhatnagar S, Dallman M (1998) Neuroanatomical basis for facilitation of hypothalamic-pituitary-adrenal responses to a novel stressor after chronic stress. Neuroscience 84:1025-1039.

Bitran D, Shiekh M, Dowd A, Dugan MM, Renda P (1998) Corticosterone is permissive to the anxiolytic effect that results from the blockade of hippocampal mineralocorticoid receptors. Pharmacol Biochem Behav 60:879-887.

Brady LS, Whitfield Jr HJ, Fox RJ, Gold PW, Herkenham M (1991) Long-term antidepressant administration alters corticotropin-releasing hormone, tyrosine hydroxylase, and mineralocorticoid receptor gene expression in rat brain. Therapeutic implications. J Clin Invest $87: 831-837$.

Chalmers DT, Lovenberg TW, De Souza EB (1995) Localization of novel corticotropin-releasing factor receptor (CRF(2)) mRNA expression to specific subcortical nuclei in rat brain: comparison with CRF(1) receptor mRNA expression. J Neurosci 15:6340-6350.

Curtis AL, Lechner SM, Pavcovich LA, Valentino RJ (1997) Activation of the locus coeruleus noradrenergic system by intracoerulear microinfusion of corticotropin-releasing factor: effects on discharge rate, cortical norepinephrine levels and cortical electroencephalographic activity. J Pharmacol Exp Ther 281:163-172.

Dallman MF, Akana SF, Cascio CS, Darlington DN, Jacobson L, Levin N (1987) Regulation of ACTH secretion: variations on a theme of B. Rec Prog Horm Res 43:113-173.

De Kloet ER, Reul JMHM (1987) Feedback action and tonic influence of corticosteroids on brain function: a concept arising from the heterogeneity of brain receptor systems. Psychoneuroendocrinology 12:83-105.

De Kloet ER, Vreugdenhil E, Oitzl MS, Joëls M (1998) Brain corticosteroid receptor balance in health and disease. Endocr Rev 19:269-301.

Deuschle M, Weber B, Colla M, Müller M, Kniest A, Heuser I (1998) 
Mineralocorticoid receptor also modulates basal activity of hypothalamus-pituitary-adrenocortical system in humans. Neuroendocrinology 68:355-360.

Evans RM, Arriza JL (1989) A molecular framework for the actions of glucocorticoid hormones in the nervous system. Neuron 2:1105-1112.

Gerlach JL, McEwen BS (1972) Rat brain binds adrenal steroid hormone: radioautography of hippocampus with corticosterone. Science 175:1133-1136.

Gold PW, Loriaux DL, Roy A, Kling MA, Calabrese JR, Kellner CH, Nieman LK, Post RM, Pickar D, Gallucci W, Avgerinos P, Paul S, Oldfield EH, Cutler GBJ, Chrousos GP (1986) Responses to corticotropin-releasing hormone in the hypercortisolism of depression and Cushing's disease. Pathophysiologic and diagnostic implications. N Engl J Med 314:1329-1335.

Hassan AHS, Von Rosenstiel P, Patchev VK, Holsboer F, Almeida OFX (1997) Exacerbation of apoptosis in the dentate gyrus of the aged rat by dexamethasone and the protective role of corticosterone. Exp Neurol 140:43-52.

Herman JP, Cullinan WE (1997) Neurocircuitry of stress: central control of the hypothalamo-pituitary-adrenocortical axis. Trends Neurosci 20:78-84.

Herman JP, Watson SJ (1995) Stress regulation of mineralocorticoid receptor heteronuclear RNA in rat hippocampus. Brain Res 677:243-249.

Herman JP, Patel PD, Akil H, Watson SJ (1989) Localization and regulation of glucocorticoid and mineralocorticoid receptor messenger RNAs in the hippocampal formation of the rat. Mol Endocrinol 3:1886-1894

Holsboer F (1999) The rationale for corticotropin-releasing hormone receptor (CRH-R) antagonists to treat depression and anxiety. J Psychiatr Res 33:181-214.

Holsboer F (2000) The corticosteroid receptor hypothesis of depression. Neuropsychopharmacology 23:477-501.

Holsboer F, Barden N (1996) Antidepressants and hypothalamicpituitary-adrenocortical regulation. Endocr Rev 17:187-205.

Holsboer F, Von Bardeleben U, Gerken A, Stalla GK, Müller OA (1984) Blunted corticotropin and normal cortisol response to human corticotropin-releasing factor in depression. N Engl J Med 311:1127.

Joëls M, De Kloet ER (1990) Mineralocorticoid receptor-mediated changes in membrane properties of rat CA1 pyramidal neurons in vitro. Proc Natl Acad Sci USA 87:4495-4498.

Joëls M, Hesen W, De Kloet ER (1991) Mineralocorticoid hormones suppress serotonin-induced hyperpolarization of rat hippocampal CA1 neurons. J Neurosci 11:2288-2294.

Korte SM, Bouws GAH, Bohus B (1993) Central actions of corticotropin-releasing hormone $(\mathrm{CRH})$ on behavioral neuroendocrine, and cardiovascular regulation: brain corticoid receptor involvement. Horm Behav 27:167-183.

Levine S (1967) Maternal and environmental influences on the adrenocortical response to stress in weanling rats. Science 156:258-260.

Linthorst ACE, Flachskamm C, Reul JMHM (1999) Effect of forced swimming on hippocampal serotonergic neurotransmission in the rat: role of Corticotropin-releasing hormone. Soc Neurosci Abstr 25: 437.

Lopez JF, Chalmers DT, Little KY, Watson SJ (1998) Regulation of serotonin1A, glucocorticoid, and mineralocorticoid receptor in rat and human hippocampus: implications for the neurobiology of depression. Biol Psychiatry 43:547-573.

Maccari S, Mormède P, Piazza PV, Simon H, Angelucci L, Le Moal M (1992) Hippocampal type I and type II corticosteroid receptors are modulated by central noradrenergic systems. Psychoneuroendocrinology 17:103-112.

Meaney MJ, Aitken DH, Van Berkel C, Bhatnagar S, Sapolsky RM (1988) Effect of Neonatal Handling on Age-Related Impairments Associated with the Hippocampus. Science 239:766-768.

Meaney MJ, Aitken DH, Viau V, Sharma S, Sarrieau A (1989) Neonatal handling alters adrenocortical negative feedback sensitivity and hippocampal type II glucocorticoid receptor binding in the rat. Neuroendocrinology 50:597-604.

Meaney MJ, Aitken DH, Sharma S, Viau V (1992) Basal ACTH, corticosterone and corticosterone-binding globulin levels over the diurnal cycle, and age-related changes in hippocampal type I and type II corticosteroid receptor binding capacity in young and aged, handled and nonhandled rats. Neuroendocrinology 55:204-213.

Meaney MJ, Diorio J, Francis D, Widdowson J, Laplante P, Caldji C, Sharma S, Seckl JR, Plotsky PM (1996) Early environmental regulation of forebrain glucocorticoid receptor gene expression: implications for adrenocortical responses to stress. Dev Neurosci 18:49-72.

Meijer OC, De Kloet ER (1998) Corticosterone and serotonergic neurotransmission in the hippocampus: functional implications of central corticosteroid receptor diversity. Crit Rev Neurobiol 12:1-20.

Meyer U, van Kampen M, Isovich E, Flügge G, Fuchs E (2000) Chronic psychosocial stress regulates the expression of both GR and MR mRNA in the hippocampal formation of tree shrews. Hippocampus, in press.

Mitchell JB, Rowe W, Boksa P, Meaney MJ (1990) Serotonin regulates
type-II corticosteroid receptor binding in hippocampal cell cultures. J Neurosci 10:1745-1752.

Nemeroff CB, Widerlöv E, Bissette G, Walléus H, Karlsson I, Eklund K, Kilts CD, Loosen PT, Vale W (1984) Elevated concentrations of CSF corticotropin-releasing factor-like immunoreactivity in depressed patients. Science 226:1342-1344.

Nemeroff CB, Owens MJ, Bissette G, Andorn AC, Stanley M (1988) Reduced corticotropin-releasing factor binding sites in the frontal cortex of suicide victims. Arch Gen Psychiatry 45:577-579.

Oitzl MS, Fluttert M, De Kloet ER (1994) The effect of corticosterone on reactivity to spatial novelty is mediated by central mineralocorticosteroid receptors. Eur J Neurosci 6:1072-1079.

Oitzl MS, Van Haarst AD, Sutanto W, De Kloet ER (1995) Corticosterone, brain mineralocorticoid receptors (MRs) and the activity of the hypothalamic-pituitary-adrenal (HPA) axis: the Lewis rat as an example of increased central MR capacity and a hyporesponsive HPA axis. Psychoneuroendocrinology 20:655-675.

Owens MJ, Nemeroff CB (1991) Physiology and pharmacology of corticotropin-releasing factor. Pharmacol Rev 43:425-473.

Pavlides C, Kimura A, Magarinos AM, McEwen BS (1994) Type I adrenal steroid receptors prolong hippocampal long- term potentiation. NeuroReport 5:2673-2677.

Raadsheer FC, Hoogendijk WJG, Stam FC, Tilders FJH, Swaab DF (1994) Increased numbers of corticotropin-releasing hormone expressing neurons in the hypothalamic paraventricular nucleus of depressed patients. Neuroendocrinology 60:436-444.

Raadsheer FC, Vanheerikhuize JJ, Lucassen PJ, Hoogendijk WJG, Tilders FJH, Swaab DF (1995) Corticotropin-releasing hormone mRNA levels in the paraventricular nucleus of patients with Alzheimer's disease and depression. Am J Psychiatry 152:1372-1376.

Ratka A, Sutanto W, Bloemers M, De Kloet ER (1989) On the role of brain mineralocorticoid (type-I) and glucocorticoid (type-II) receptors in neuroendocrine regulation. Neuroendocrinology 50:117-123.

Reul JMHM, De Kloet ER (1985) Two receptor systems for corticosterone in rat brain: microdistribution and differential occupation. Endocrinology 117:2505-2512.

Reul JMHM, De Kloet ER (1986) Anatomical resolution of two types of corticosterone receptor sites in rat brain with in vitro autoradiography and computerized image analysis. J Steroid Biochem 24:269-272.

Reul JMHM, Van den Bosch FR, De Kloet ER (1987a) Relative occupation of type-I and type-II corticosteroid receptors in rat brain following stress and dexamethasone treatment: functional implications. J Endocrinol 115:459-467.

Reul JMHM, Van den Bosch FR, De Kloet ER (1987b) Differential response of type I and type II corticosteroid receptors to changes in plasma steroid level and circadian rhythmicity. Neuroendocrinology 45:407-412.

Reul JMHM, Tonnaer JADM, De Kloet ER (1988) Neurotrophic ACTH analogue promotes plasticity of type I corticosteroid receptor in brain of senescent male rats. Neurobiol Aging 9:253-260.

Reul JMHM, Pearce PT, Funder JW, Krozowski ZS (1989) Type I and type II corticosteroid receptor gene expression in the rat: effect of adrenalectomy and dexamethasone administration. Mol Endocrinol 3:1674-1680.

Reul JMHM, Sutanto W, Van Eekelen JAM, Rothuizen J, De Kloet ER (1990) Central action of adrenal steroids during stress and adaptation. In: Circulating regulatory factors and neuroendocrine function, $p p$ 243-256. New York: Plenum

Reul JMHM, Stec I, Söder M, Holsboer F (1993) Chronic treatment of rats with the antidepressant amitriptyline attenuates the activity of the hypothalamic-pituitary-adrenocortical system. Endocrinology 133:312320

Reul JMHM, Labeur MS, Grigoriadis DE, De Souza EB, Holsboer F (1994) Hypothalamic-pituitary-adrenocortical axis changes in the rat after long-term treatment with the reversible monoamine oxidase-A inhibitor moclobemide. Neuroendocrinology 60:509-519.

Reul JMHM, Gesing A, Droste S, Stec ISM, Weber A, Bachmann C, Bilang-Bleuel A, Holsboer F, Linthorst ACE (2000) The brain mineralocorticoid receptor: greedy for ligand, mysterious in function. Eur J Pharmacol 405:235-249.

Seck1 JR, Dickson KL, Fink G (1990) Central 5,7-dihydroxytryptamine lesions decrease hippocampal glucocorticoid and mineralocorticoid receptor messenger ribonucleic acid expression. J Neuroendocrinology 2:911-916.

Sloviter RS, Valiquette G, Abrams GM, Ronk EC, Sollas AL, Paul LA, Neubort S (1989) Selective loss of hippocampal granule cells in the mature rat brain after adrenalectomy. Science 243:535-538.

Smythe JW, Murphy D, Timothy C, Costall B (1997) Hippocampal mineralocorticoid, but not glucocorticoid, receptors modulate anxiety-like behavior in rats. Pharmacol Biochem Behav 56:507-513.

Spencer RL, Young EA, Choo PH, McEwen BS (1990). Adrenal steroid type-I and type-II receptor binding: estimates of in vivo receptor number, occupancy, and activation with varying level of steroid. Brain Res 514:37-48.

Spencer RL, Miller AH, Stein M, McEwen BS (1991) Corticosterone 
regulation of type I and type II adrenal steroid receptors in brain, pituitary and immune tissue. Brain Res 549:236-246.

Sutanto W, Rosenfeld P, De Kloet ER, Levine S (1996) Long-term effects of neonatal maternal deprivation and ACTH on hippocampal mineralocorticoid and glucocorticoid receptors. Dev Brain Res 92:156-163.

Swaab DF, Raadsheer FC, Endert E, Hofman MA, Kamphorst W, Ravid R (1994) Increased cortisol levels in aging and Alzheimer's disease in postmortem cerebrospinal fluid. J Neuroendocrinol 6:681-687.

Vallée M, Mayo W, Dellu F, Le Moal M, Simon H, Maccari S (1997) Prenatal stress induces high anxiety and postnatal handling induces low anxiety in adult offspring: correlation with stress-induced corticosterone secretion. J Neurosci 17:2626-2636.

Van Haarst AD, Oitzl MS, De Kloet ER (1997) Facilitation of feedback inhibition through blockade of glucocorticoid receptors in the hippocampus. Neurochem Res 22:1323-1328.

Vaughan J, Donaldson C, Bittencourt J, Perrin MH, Lewis K, Sutton S, Chan R, Turnbull AV, Lovejoy D, Rivier C, Rivier J, Sawchenko PE, Vale W (1995) Urocortin, a mammalian neuropeptide related to fish urotensin I and to corticotropin-releasing factor. Nature 378:287-292.

Vedder H, Weiss I, Holsboer F, Reul JMHM (1993) Glucocorticoid and mineralocorticoid receptors in rat neocortical and hippocampal brain cells in culture: characterization and regulatory studies. Brain Res 605:18-24.

Whitnall MH (1993) Regulation of the hypothalamic corticotropinreleasing hormone neurosecretory system. Prog Neurobiol 40:573629. 